Article

\title{
Comparative Analysis of Herbaceous and Woody Cell Wall Digestibility by Pathogenic Fungi
}

\author{
Yanhua Dou ${ }^{1,2,+}$, Yan Yang ${ }^{3,+}$, Nitesh Kumar Mund ${ }^{1,2} \oplus$, Yanping Wei ${ }^{1,2} \oplus$, Yisong Liu ${ }^{1,2}$, Linfang Wei ${ }^{1,2}$, \\ Yifan Wang ${ }^{1,2}$, Panpan Du 1,2, Yunheng Zhou ${ }^{1,2}$, Johannes Liesche 1,2 ${ }^{1}$, Lili Huang $4{ }^{1}$, Hao Fang ${ }^{1,2}$, \\ Chen Zhao ${ }^{1,2}$, Jisheng $\mathrm{Li}^{1,2}$, Yahong Wei ${ }^{1,2,5, * \mathbb{D}}$ and Shaolin Chen ${ }^{1,2,5, *}$
}

1 College of Life Sciences, Northwest A\&F University, Yangling, Xianyang 712100, China; yhdou_iris@nwafu.edu.cn (Y.D.); mund.nitesh@gmail.com (N.K.M.); weiyanping@genecompany.com (Y.W.); yisliu2021@126.com (Y.L.); weilf@nwafu.edu.cn (L.W.); wyfyffs@126.com (Y.W.); tkj@nwafu.edu.cn (P.D.); zhouyunheng@nwafu.edu.cn (Y.Z.); liesche@nwafu.edu.cn (J.L.); fanghao@nwafu.edu.cn (H.F.); chenzhao@nwafu.edu.cn (C.Z.); lijsh2011@163.com (J.L.)

2 Biomass Energy Center for Arid and Semi-Arid Lands, Northwest A\&F University, Yangling, Xianyang 712100, China

3 College of Chemistry and Chemical Engineering, Shanxi Datong University, Datong 037009, China; DTDXHXSHD@126.com

4 College of Plant Protection, Northwest A\&F University, Yangling, Xianyang 712100, China; lilyhuangk@163.com

5 Shaanxi Key Laboratory of Agricultural and Environmental Microbiology, Northwest A\&F University, Yangling, Xianyang 712100, China

* Correspondence: yahongwei@nwafu.edu.cn (Y.W.); slc1916@nwsuaf.edu.cn (S.C.); Tel.: +86-029-87091021 (S.C.)

check for

updates

Citation: Dou, Y.; Yang, Y.; Mund, N.K.; Wei, Y.; Liu, Y.; Wei, L.; Wang, Y.; Du, P.; Zhou, Y.; Liesche, J.; et al. Comparative Analysis of Herbaceous and Woody Cell Wall Digestibility by Pathogenic Fungi. Molecules 2021, 26, 7220. https://doi.org/10.3390/ molecules26237220

Academic Editor: Pietro Russo

Received: 23 October 2021

Accepted: 25 November 2021

Published: 28 November 2021

Publisher's Note: MDPI stays neutral with regard to jurisdictional claims in published maps and institutional affiliations.

Copyright: (c) 2021 by the authors. Licensee MDPI, Basel, Switzerland. This article is an open access article distributed under the terms and conditions of the Creative Commons Attribution (CC BY) license (https:// creativecommons.org/licenses/by/ $4.0 /)$.
+ These authors contributed equally to this work.

Abstract: Fungal pathogens have evolved combinations of plant cell-wall-degrading enzymes (PCWDEs) to deconstruct host plant cell walls (PCWs). An understanding of this process is hoped to create a basis for improving plant biomass conversion efficiency into sustainable biofuels and bioproducts. Here, an approach integrating enzyme activity assay, biomass pretreatment, field emission scanning electron microscopy (FESEM), and genomic analysis of PCWDEs were applied to examine digestibility or degradability of selected woody and herbaceous biomass by pathogenic fungi. Preferred hydrolysis of apple tree branch, rapeseed straw, or wheat straw were observed by the apple-tree-specific pathogen Valsa mali, the rapeseed pathogen Sclerotinia sclerotiorum, and the wheat pathogen Rhizoctonia cerealis, respectively. Delignification by peracetic acid (PAA) pretreatment increased PCW digestibility, and the increase was generally more profound with non-host than host PCW substrates. Hemicellulase pretreatment slightly reduced or had no effect on hemicellulose content in the PCW substrates tested; however, the pretreatment significantly changed hydrolytic preferences of the selected pathogens, indicating a role of hemicellulose branching in PCW digestibility. Cellulose organization appears to also impact digestibility of host PCWs, as reflected by differences in cellulose microfibril organization in woody and herbaceous PCWs and variation in cellulose-binding domain organization in cellulases of pathogenic fungi, which is known to influence enzyme access to cellulose. Taken together, this study highlighted the importance of chemical structure of both hemicelluloses and cellulose in host PCW digestibility by fungal pathogens.

Keywords: cellulose; hemicelluloses; lignin; apple tree branch; wheat straw; rapeseed straw; digestibility; pathogenic fungi; CAZyme; cellulase; hemicellulases

\section{Introduction}

Production of biofuels and sustainable bioproducts from plant biomass benefits the environment by reducing greenhouse gas emissions [1]. However, low efficiency of enzymatic hydrolysis of cellulosic biomass to fermentable sugars is still a major challenge for 
cost-effective production of biofuels and bioproducts [2-4]. Further improvement of this process depends on a deeper understanding of the relationship between biomass cell wall structure and enzymatic digestibility $[5,6]$.

Cell wall material from the plant species, such as monocot grasses, herbaceous dicots, and woody dicots, has been used as candidate biomass feedstocks for the production of biofuels and bioproducts [7]. Despite great progress in investigating PCW recalcitrance, few studies have compared the enzymatic digestibility of herbaceous and woody biomass by pathogenic fungi. Different woody and herbaceous biomass have distinguishable PCW compositions, polymer features, and structures [8,9]. For instance, substitutions on xylans, the major component of the secondary cell walls (SCWs) of dicotyledonous and grass plants, are diverse and vary phylogenetically $[10,11]$. Eudicot xylans are acetylated, whereas monocot xylans are acetylated and highly arabinosylated [12]. The different substitutions affect both the self-association properties of the xylan polymer and its interaction with cellulose and lignin $[13,14]$.

To compare the impact of hemicelluloses and lignin on the digestibility of herbaceous and woody plant cell walls, we assessed the hydrolysis profile of plant biomass from herbaceous monocots (wheat and switchgrass straw), herbaceous dicot (rapeseed straw), and woody dicot (apple tree branch) by selected plant pathogens before and after hemicellulase or peracetic acid (PAA) pretreatment. Hemicellulase pretreatment makes changes to not only the main chains of polysaccharides but also branching decoration with sugars (i.e., mono- or oligosaccharides) or non-sugars (i.e., acetylation, methylation, or feruloylation) in main chains [15]. PAA, a relatively inexpensive reagent, can reduce the degree of polymerization of lignin and increase its solubility in water at relatively low temperatures [16]. After PAA pretreatment, which exposed surface fibrillar cellulose, field emission scanning electron microscopy (FESEM) was applied to examine the differences of surface cellulose organization between woody and herbaceous cell wall substrates.

Effects of hemicellulase and PAA pretreatment on host substrate preferences were further compared with their pathogenic fungi (Table 1). In addition to the promising energy crop switchgrass (SG), wheat straw (WS) and rapeseed straw (RS) were used as representative residues of major monocot and dicot crops in Northwest China $[17,18]$. Wood branches were rich in certain areas and apple tree branch (AB) was selected as it has the largest production in non-forest areas in Northwest China [19]. Valsa mali, an appletree-specific pathogen [20], was used as a woody plant pathogen. Botryosphaeria dothidea, which infects various woody species including apple tree [21,22], was used as a comparison to the apple-tree-specific V. mali. Another comparison was made with Colletotrichum gloeosporioides, which infects a broad range of hosts, including woody and herbaceous plants [23]. Sclerotinia sclerotiorum was used as a representative herbaceous dicot pathogen that infects rapeseed [24], while Bipolaris sorokiniana [25,26], Gaeumannomyces graminis [27], Fusarium graminearum [28-30], and Rhizoctonia cerealis [31,32] were used as herbaceous monocot pathogens that infect wheat. Comparing the hydrolytic activities of the selected pathogens would help determine whether the pathogens have host preferences. Pretreatment by PAA and hemicellulases helps examine if lignin and hemicelluloses impact the digestibility of host PCWs by pathogenic fungi. Our previous studies suggest that mutations in cellulose synthases influence not only cellulose synthesis and deposition [33,34] but also PCW porosity [35], a critical parameter affecting the accessibility of cellulose to cellulolytic enzymes [36]. To examine if cellulose contributes to host PCW digestibility, we visualized cellulose organization in the PCW biomass tested using FESEM and analyzed the sequences and domain organization of GH6 and GH7 cellobiohydrolases (CBHs), the major components of fungal cellulases [37]. Taken together, this initial investigation aims to provide a basis for further exploration of the interactive relationships among cellulose, hemicellulose, and lignin in host PCWs and PCWDEs evolved by pathogenic fungi to overcome the recalcitrance of PCWs. 
Table 1. Fungal pathogens used in this study.

\begin{tabular}{|c|c|c|c|c|}
\hline Pathogenic Species & Phylum & Host & Disease & Reference \\
\hline Bipolaris sorokiniana & Ascomycota & $\begin{array}{l}\text { Cereals (e.g., wheat) and } \\
\text { grasses (e.g., switchgrass). }\end{array}$ & $\begin{array}{c}\text { Causes disease on the root, } \\
\text { leaf and stem, and } \\
\text { head tissue. }\end{array}$ & {$[25,26]$} \\
\hline Fusarium graminearum & Ascomycota & $\begin{array}{l}\text { Cereals (e.g., wheat) and } \\
\text { grasses (e.g., switchgrass) }\end{array}$ & $\begin{array}{l}\text { Causes Fusarium head } \\
\text { blight and Gibberella ear } \\
\text { rot and stalk rot. }\end{array}$ & [28-30] \\
\hline Gaeumannomyces graminis & Ascomycota & $\begin{array}{l}\text { Cereals (e.g., wheat) } \\
\text { and grasses. }\end{array}$ & $\begin{array}{l}\text { Colonizes the root and } \\
\text { crown tissue, causing } \\
\text { Turfgrass disease. }\end{array}$ & [27] \\
\hline Rhizoctonia cerealis & Basidiomycota & $\begin{array}{l}\text { Cereals (e.g., wheat) and } \\
\text { grasses (e.g., switchgrass) }\end{array}$ & $\begin{array}{c}\text { Causes sharp eyespot and } \\
\text { root rot. }\end{array}$ & {$[31,32]$} \\
\hline Sclerotinia sclerotiorum & Ascomycota & $\begin{array}{c}\text { Dicotyledonous } \\
\text { herbaceous species } \\
\text { (e.g., rapeseed, soybean) }\end{array}$ & $\begin{array}{l}\text { Causes Sclerotinia head rot, } \\
\text { Sclerotinia stalk rot, and } \\
\text { Sclerotinia wilt. }\end{array}$ & [24] \\
\hline Valsa mali var. mali & Ascomycota & Apple tree & $\begin{array}{c}\text { Preferentially infects apple } \\
\text { trees, causing } \\
\text { canker diseases. }\end{array}$ & {$[20,38]$} \\
\hline Botryosphaeria dothidea & Ascomycota & $\begin{array}{l}\text { Trees and shrubs } \\
\text { (e.g., apple and other } \\
\text { fruit trees) }\end{array}$ & $\begin{array}{l}\text { Disease symptoms are } \\
\text { associated with twig, } \\
\text { branch and stem cankers, } \\
\text { tip and branch dieback, } \\
\text { fruit rot, etc. }\end{array}$ & {$[21,22]$} \\
\hline $\begin{array}{c}\text { Colletotrichum } \\
\text { gloeosporioides (teleomorph: } \\
\text { Glomerella cingulata) }\end{array}$ & Ascomycota & $\begin{array}{l}\text { Trees (e.g., apple tree), } \\
\text { cereals and grasses, } \\
\text { legumes, vegetables }\end{array}$ & Causes anthracnose disease & [23] \\
\hline
\end{tabular}

\section{Results and Discussion}

2.1. Extracts from Valsa mali, B. sorokiniana, and S. sclerotiorum Showed Significant Hydrolytic Preferences for Apple Tree Branch, Wheat Straw, and Rapeseed Straw, Respectively

To compare the digestibility of herbaceous and woody PCWs by pathogenic fungi, the biomass residues selected include apple tree branch (woody dicot), rapeseed straw (herbaceous dicot), and wheat and switchgrass straw (herbaceous monocot). Valsa mali was used as a representative woody pathogen as it specifically infects apple trees [20]. PCWDEs from $V$. mali and other pathogenic fungi were extracted from the cultures grown on switchgrass, which has been shown to have a similar PCWDE induction profile to other substrates [39]. As shown in Figure 1A, the extracts from V. mali showed a significant preference for the biomass of apple tree branch (AB), with approximately one-fold higher lignocellulolytic activity on AB than that on wheat straw (WS), switchgrass straw (SW), and rapeseed straw (RS) (Figure 2). A significant preference of $V$. mali for the biomass of $\mathrm{AB}$ correlated with the host preference of this pathogen for apple trees (Table 1) [20]. The extracts of C. gloeosporioides also showed greater hydrolysis in AB than WS, SW, and RS, while this pathogenic fungi infects not only apple trees and other woody plants, but also herbaceous plants [23]. By contrast, the extracts of B. dothidea, another common pathogen that occurs on a large number of hosts [22], did not show higher hydrolysis in AB but SW and RS. On the other hand, the extracts of pathogens for cereals and grasses, including G. graminis, F. graminearum, and R. cerealis, exhibited greater hydrolysis on the cereal and grass biomass tested (i.e., WS, SG, and RS) than the woody biomass of AB (Figure 1A). In particular, the extracts of B. sorokiniana and $S$. sclerotiorum showed significant host preferences for WS and RS, respectively. Taken together, the results corroborate the finding that hydrolytic preferences for biomass type were generally correlated with host preferences of the plant pathogens tested [39]. 

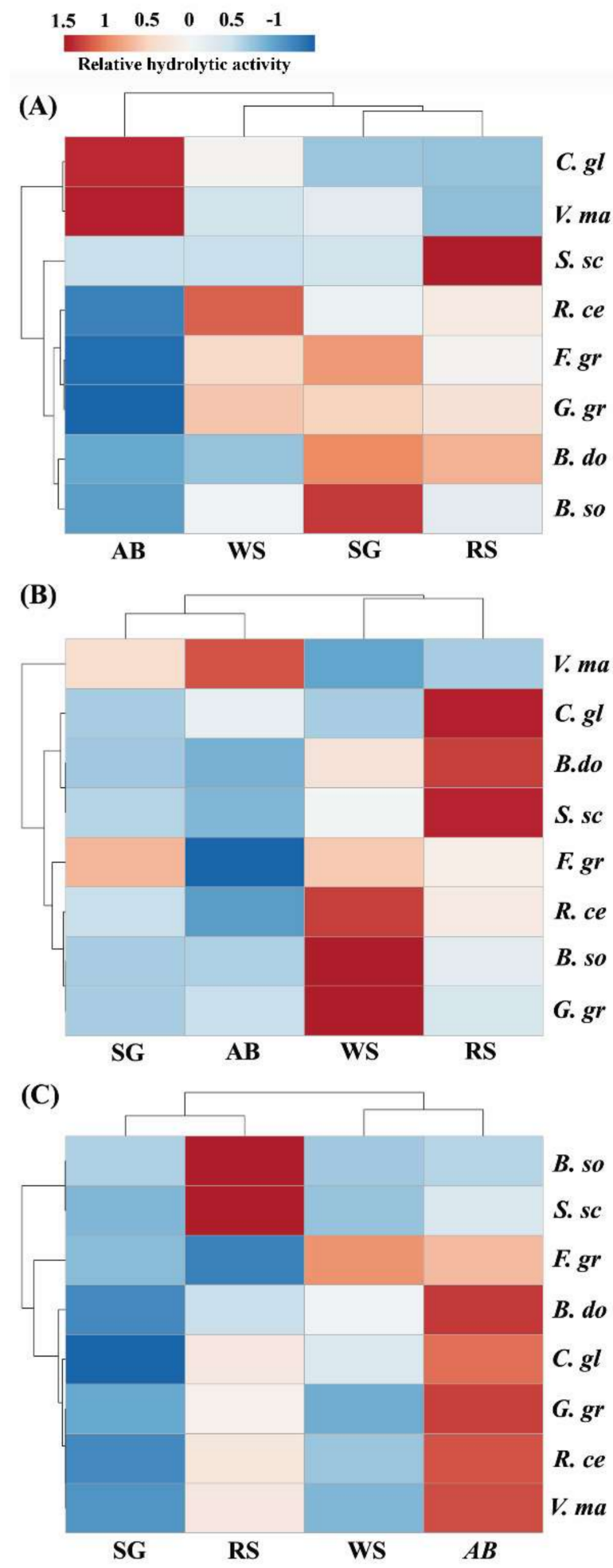

Figure 1. Hierarchical clustering of the pathogenic fungi tested. Heatmap showing the mean activities and clustering of 8 species of plant pathogenic fungi (B. do, Botryosphaeria dothidea; B. so, Bipolaris sorokiniana; C. gl, Colletotrichum gloeosporioides; F. gr, Fusarium graminearum; G. gr, Gaeumannomyces graminis; S. sc, Sclerotinia sclerotiorum; V. ma, Valsa mali), when assayed for hydrolysis of 4 crop residues (AB, apple tree branch; WS, wheat straw; SG, switchgrass straw; RS, rapeseed straw) untreated (A) or pretreated by hemicellulases (B) or PAA (C). The activity assay was performed as described in a previous study [39]. 


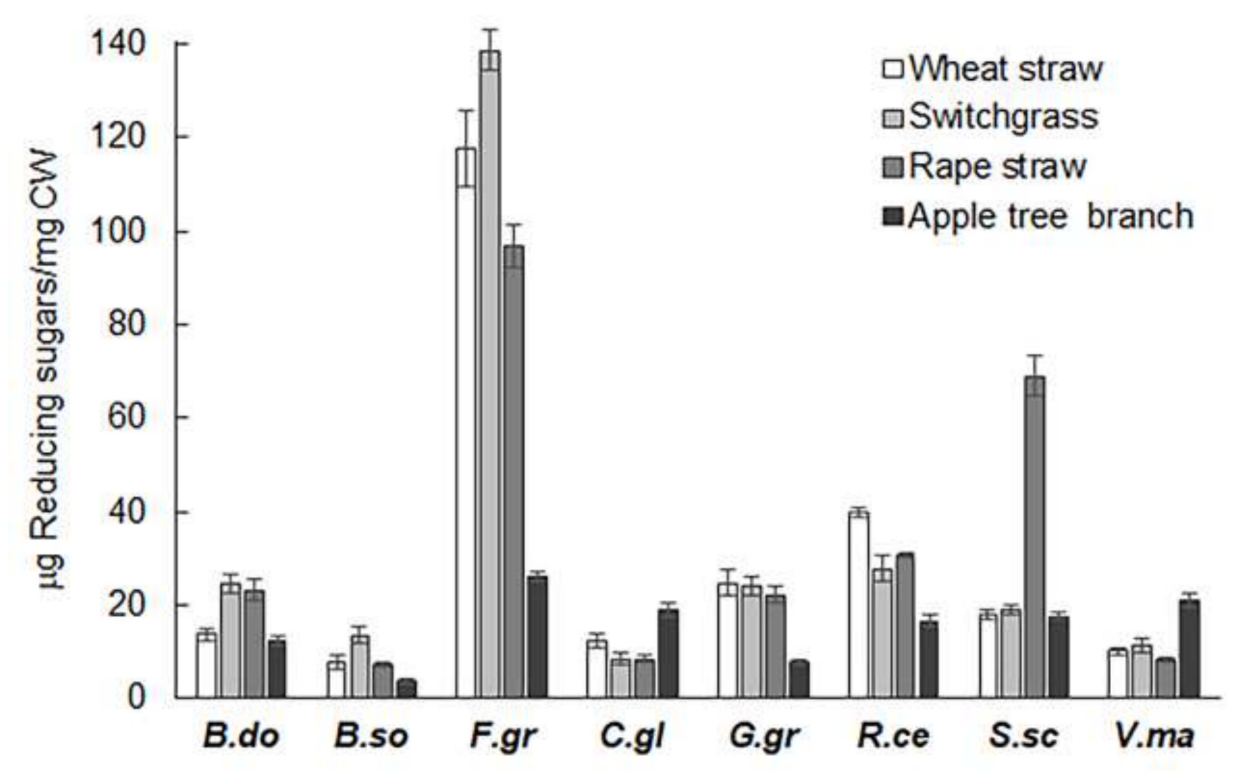

Figure 2. Enzymatic hydrolysis of cell wall substrates of wheat straw, switchgrass straw, rapeseed straw, and apple tree branch. Y axis depicts the amount of reducing sugars released after incubation of untreated cell wall substrates with extracts from the cultures of pathogenic fungi grown on switchgrass, as described previously [39].

\subsection{Hemicellulase Pretreatment Modulated Hydrolytic Preferences of Pathogenic Fungi for Biomass Type}

As shown in previous studies [40,41], hemicellulases, such as xylanases and feruloyl esterases, are required for virulence of some plant pathogens. Disruption or silencing of xylanase genes in $\mathrm{V}$. mali and other plant pathogens have been shown to cause defects in virulence $[40,42,43]$. Feruloyl esterases, a subclass of carboxylic esterases (CEs), cleave ester bonds that crosslink hemicellulose and lignin. Deletion of feruloyl esterase genes in V. mali and other plant pathogens also caused a reduction in pathogenesis [41,44].

To examine if hemicellulases play a role in hydrolytic preferences of the pathogenic fungi tested, biomass substrates were pretreated by hemicellulases from the saprophytic fungus Aspergillus niger (Hemicellulase H2125, Sigma), which contains a mixture of xylanases and other hemicellulases. Compared to no pretreatment, hemicellulase pretreatment caused significant changes in hydrolytic preferences of the pathogens tested. For instance, hemicellulase pretreatment switched the hydrolytic preference of $C$. gloeosporioides from $\mathrm{AB}$ to WS, while the pretreatment switched the preference of G. graminis from WS, SG, and RS to WS (Figure 1B). It was also notewothy that hemicellulase pretreatment showed differential effects on the digestibility of PCW substrates (Figure 3A,B). The pretreatment reduced the hydrolytic activities of $F$. graminearum on all the crop residues tested. The antagonistic effect was also observed with $B$. dothidea on SG and AB, B. sorokiniana on SG, C. gloeosporioides on WS and $\mathrm{AB}, \mathrm{G}$. graminis on $\mathrm{SG}$ and $\mathrm{RS}, R$. cerealis on $\mathrm{SG}$ and $\mathrm{AB}, \mathrm{S}$. scierotiorum on $\mathrm{SG}$ and $\mathrm{AB}$, and $V$. mali on $\mathrm{AB}$ (Figure $3 \mathrm{~B}$ ). On the other hand, synergistic effects of the pretreatment on PCW digestibility were observed with B. dothidea on WS and $\mathrm{AB}, \mathrm{B}$. sorokiniana on WS, RS and AB, C. gloeosporioides on RS, R. cerealis on WS, and $\mathrm{S}$. scierotiorum on WS. The results indicate diversity of hemicelluloses among herbaceous and woody plant SCWs, corroborating the idea that the molecular heterogeneity of hemicelluloses plays a key role in modulating the interactions with cellulose microfibrils [45] and the occurrence of covalent linkages with lignin [12]. 

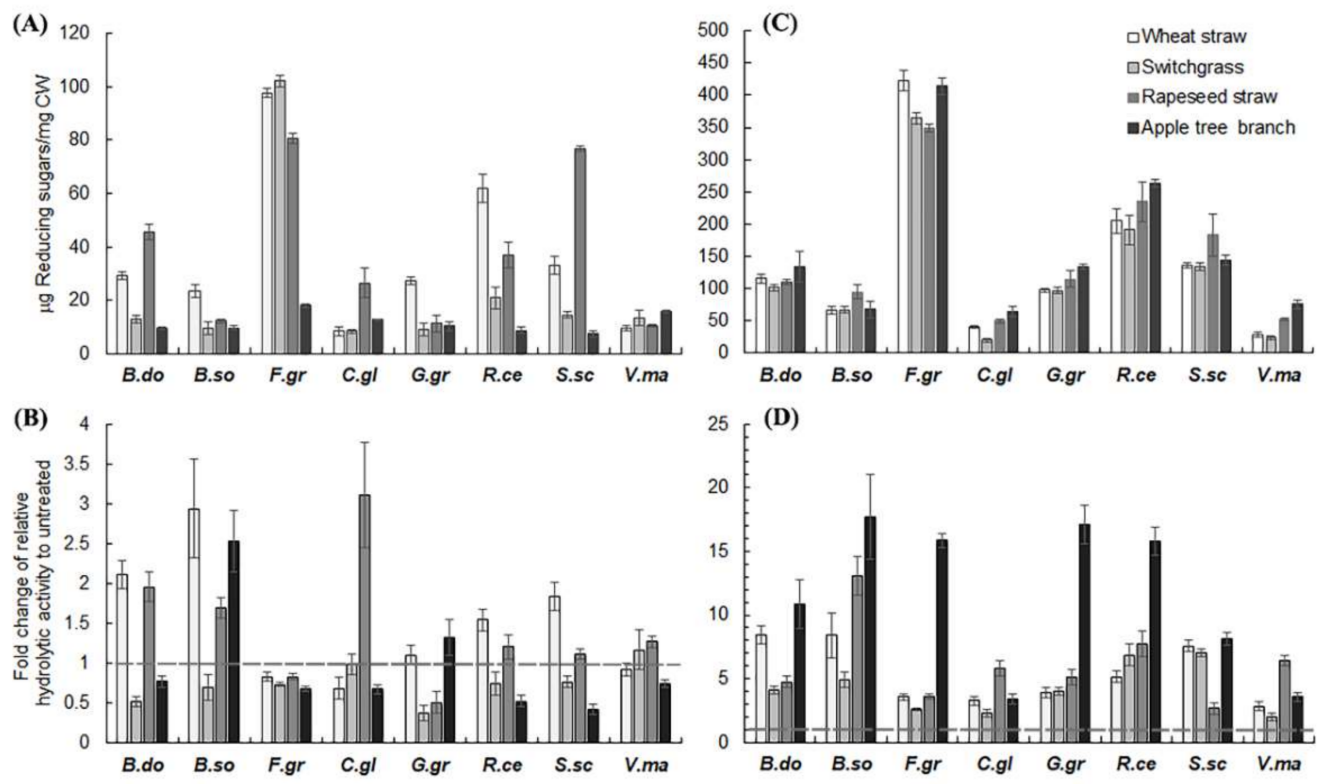

Figure 3. Enzymatic hydrolysis of cell wall substrates of wheat straw, switchgrass straw, rapeseed straw, and apple tree branch pretreated by hemicellulases (A) or PAA (C). (B,D) Fold-changes of hydrolytic activities of pathogenic fungi on hemicellulase- and PAA-pretreated substrates vs. untreated substrates, respectively.

The composition of the crop residues was also determined (Figure 4), and the derived contents of cellulose, hemicelluloses, and lignin were in the range reported in previous studies [46-54]. While slightly reduced levels of hemicelluloses were observed in the herbaceous residues of WS (Figure 4A), SG (Figure 4B), and RS (Figure 4C), hemicellulase pretreatment had no significant effect on the level of hemicelluloses in the woody residue of $\mathrm{AB}$ (Figure 4D). The observed differential effects of hemicellase pretreatment on the digestibility of the woody residue $\mathrm{AB}$ by the pathogenic fungi tested cannot simply be explained by changes in hemicellulose composition. Hemicellulases are known to cleave or modify both main chains and side chains of hemicelluloses [11], which may lead to changes in interactions or crosslinking of hemicelluloses with cellulose microfibrils [45] and lignin [12], and thus modulated porosity of PCWs or accessibility of cellulolytic enzymes to cellulose microfibrils [5].

\subsection{Delignification by PAA Pretreatment Increased Enzymatic Hydrolysis of Crop Residues and} the Increase Was Generally More Profound with Non-Host than Host Plant Biomass

To examine the effect of delignification treatment on hydrolytic preferences of pathogenic fungi for crop residues, peracetic acid (PAA) was used to treat the biomass residues tested, which can reduce the degree of polymerization of lignin and increase lignin solubility in water [16]. Compared to no pretreatment (Figure 1A), PAA pretreatment also changed hydrolytic preferences of pathogenic fungi for the crop residues tested (Figures $1 \mathrm{C}$ and 3D), but differently from hemicellulase pretreatment (Figures $1 \mathrm{~B}$ and $3 \mathrm{~B}$ ). While PAA pretreatment increased the digestibility of both the woody residue $\mathrm{AB}$ and the herbaceous residues WS, SG, and RS, differential effects of PAA pretreatment on host and non-host plant biomass were observed, as reflected by a more significant increase in the digestibility of non-host plant substrates than those of host plant substrates (Figure 3D). For instance, by the herbaceous pathogens, such as B. sorokiniana, F. graminearum, G. graminis, and $R$. cerealis, PAA pretreatment had a more significant effect on increasing the enzymatic hydrolysis of the woody substrate AB than that of the herbaceous substrates WS, SG, and RS. On the hand hand, by the woody pathogen $V$. mali, PAA pretreatment showed a more significant enhancement effect on the enzymatic hydrolysis of the herbaceous substrate RS than that of the woody substrate AB. Similarly, PAA pretreatment had a more sig- 
nificant effect on increasing the hydrolysis of non-host substrates such as WS, SG, and AB than those of the host substrate RS by S. sclerotiorum. Taken together, the differential effects of PAA pretreatment on host and non-host plant substrates reflect a key role of lignin in the diversity of cell walls among different plant species, which corroborates the idea that interactions and crosslinking among lignin, hemicelluloses, and cellulose affect emergent properties of PCWs such as mechanical strength, flexibility, and recalcitrance to enzymatic digestion $[5,12,55]$.
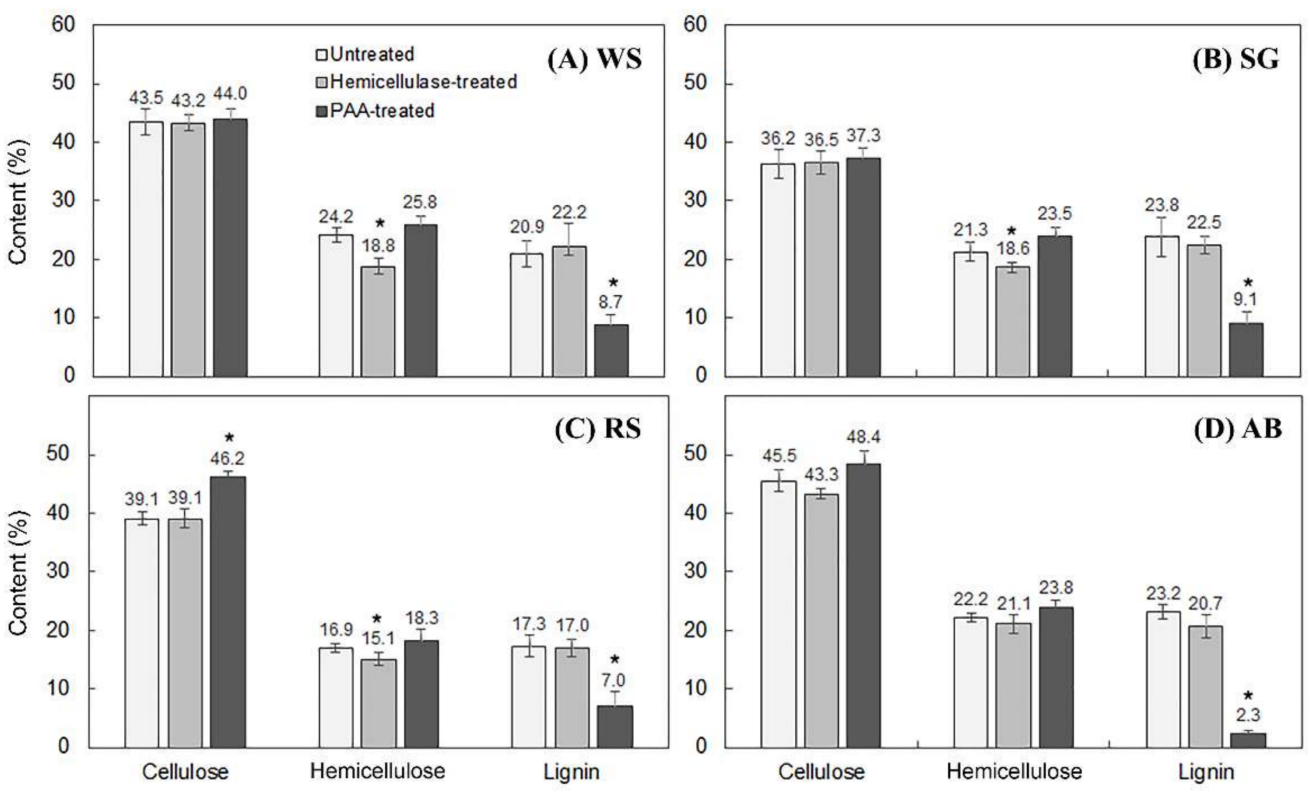

(E)

WS

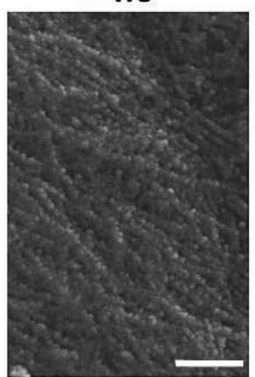

RS

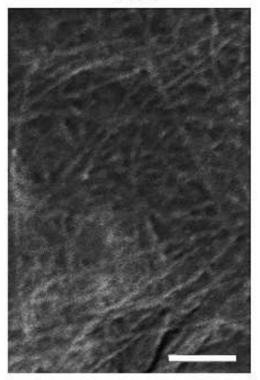

$\mathrm{AB}$

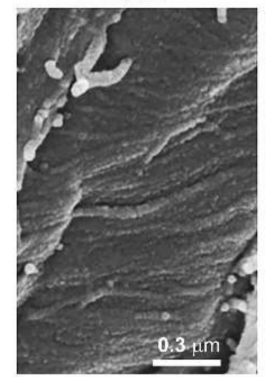

AB (splitted)

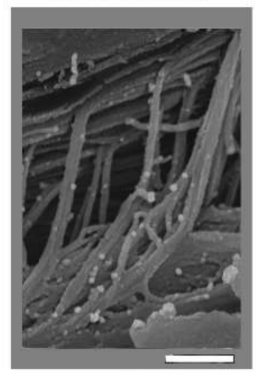

Figure 4. Compositional analysis and FESEM imaging of plant cell walls. Compositional analysis was performed with cell wall samples of (A) wheat straw (WS), (B) switchgrass straw (SG), (C) rapeseed straw (RS), and (D) apple tree branch (AB) before or after pretreatment by hemicellulases or PAA. Data are the means of three biological replicates and error bars show the standard deviation. Asterisks indicate the significant difference (determined by $t$-test) between hemicellulase-pretreated or PAApretreated and untreated crop residue biomass $(* p<0.01)$. (E) FESEM images were obtained after PAA pretreatment to expose fibrillar cellulose on cell wall surfaces. Scale bar, $0.3 \mu \mathrm{m}$.

\subsection{Cellulose Organization May Contribute to Enzymatic Digestibility of Plant Cell Walls by Pathogenic Fungi}

Our previous study using a fluorescence quenching assay revealed that mutations in cellulose synthases (CESAs) affect the nano-scale porosity of plant cell walls [35], a critical parameter determining PCW digestibility or degradability [36]. In this study, FESEM imaging was applied to examine if cellulose organization varies in different plant species. PAA treatment was applied to remove surface lignin to expose surface fibrillar cellulose. FESEM images revealed the differences of cell wall surface morphology between the woody $\mathrm{AB}$ and the herbaceous WS and RS. The surface pattern of cellulose fibrils appeared to be a relatively interwoven arrangement in the herbaceous WS and RS, while a relatively compact 
and parallel arrangement of cellulose fibrils was observed in the woody AB. Splitting of cellulose firbils caused by biomass grinding was observed in AB cell walls (Figure 4E), confirming the compact and parallel arrangement of cellulose fibrils in the SCW of woody species [56]. All together, the results suggest that chemical structure of cellulose may also contribute to enzymatic digestibility of PCWs by pathogenic fungi. This idea corroborates with studies showing that sequences of cellulose synthase (CESAs) domains, involved in the formation of CESA complexes [57], vary in plant species [58] and that phosphorylation of CESAs in these domains modulates cellulose synthesis and deposition [33,34].

Variation in chemical structure of cellulose in host plants is also reflected by domain organization and sequences of cellulases of pathogenic fungi. Representative cellulases in cellulolytic fungi include $\mathrm{CBH} 1$ and $\mathrm{CBH} 2$ [59]; their relative abundance is $60 \%$ and $20 \%$ in the exoproteome of T. reesei, respectively [37]. $\mathrm{CBH} 1$ and $\mathrm{CBH} 2$ belong to $\mathrm{GH} 7$ and GH6 families. Cellulose binding domain (CBD) (carbohydrate binding module 1) in GH6 or GH7 of the pathogenic fungi tested is generally at the $\mathrm{N}$ - or C-termini, respectively (Figure S1). According to CBD domain organization, GH6 and GH7 can be categorized into six groups (Figure 5A): (i) all GH6 and GH7 associated with a CBD (e.g., T. reesei); (ii) all GH6 and some GH7 with a CBD but other GH7 without a CBD (e.g., F. graminearum, S. sclerotiorum); (iii) some GH6 and GH7 with a CBD but others without a CBD (e.g., G. graminis, N. crassa); (iv) all GH6 with a CBD but GH7 without a CBD (e.g., B. dothidea, V. mali); (v) some GH6 with a CBD but other GH6 and all GH7 without a CBD (e.g., C. gloeosporioides); (vi) all GH6 and GH7 without a CBD (e.g., B. sorokiniana). It is noteworthy that the tree pathogens tested, including V. mali and B. dothidea, were categorized into group IV.

(A)

\begin{tabular}{ccccccc}
\hline Category & I & II & III & IV & V & VI \\
\hline GH6 with CBD & + & + & + & + & + & - \\
GH6 without CBD & + & - & - & - & + & + \\
GH7 with CBD & + & + & + & - & - & - \\
GH7 without CBD & + & + & - & + & + & + \\
Fungi & $\begin{array}{l}\text { G. } g r \\
\text { N. } c r\end{array}$ & $\begin{array}{c}\text { F. } g r \\
\text { S. sc }\end{array}$ & T. re & $\begin{array}{c}\text { B. } d o \\
\text { V. } m a\end{array}$ & C. gl & B. so \\
\hline
\end{tabular}

(B)

S.SC_A7EI03 (GH7_CBD)
S.SC_A7EAK2 (GH7_CBD)
N.cr_CBH1 (GH6_CBD)
G.gr_J3NWP9 (GH7_CBD)
F.gr_I1RAN9 (GH7_CBD)
C.gl_L2FZQ3 (GH6_CBD)
S.SC_A7E6G7 (GH6_CBD)
S.sC_A0A1D9PXY8(GH6_CBD)
B.do_288350 (GH6_CBD)
T.re_CBH1 (GH7_CBD)
T.re_EGL1 (GH7_CBD)
G.gr_J3NZ73 (GH6_CBD)
N.cr_GH6-2 (GH6_CBD)
F.gr_I1RIJ1 (GH6_CBD)
V.ma_A0A194VIP8 (GH6_CBD)
T.re_CBH2 (GH6_CBD)

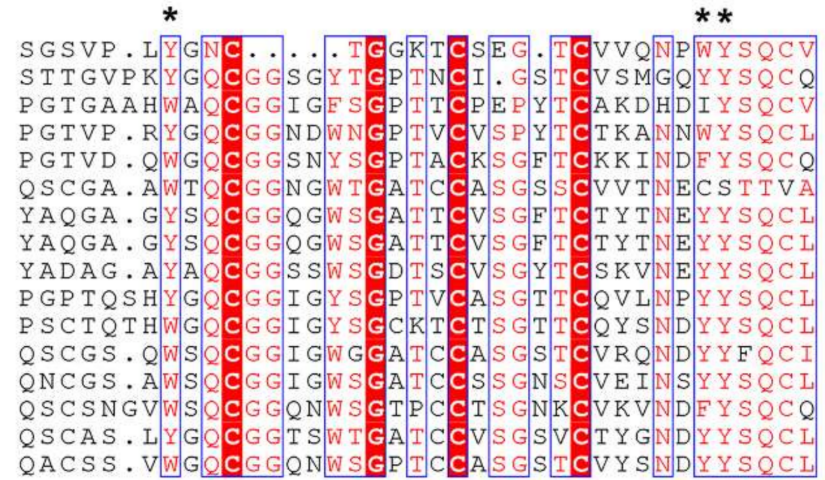

Figure 5. $\mathrm{CBD}$ organization and sequence alignment. (A) Categorization of $\mathrm{CBD}$ organization in GH6 and GH7 cellulases from the pathogenic fungi tested. + and - indicate cellulases with and without CBD, respectively. (B) Sequence alignment of CBDs in GH6 and GH7 enzymes. Red color highlights conserved residues. Black stars $\left(^{*}\right)$ are aromatic residues in the planar surface of CBD involved in cellulose binding. 
In addition to domain organization, CBDs of GH6 and GH7 enzymes also showed variation in sequences. While the amino acids $\mathrm{C} 11, \mathrm{G} 18, \mathrm{C} 22$, and $\mathrm{C} 28$, according to the numbering of $T$. reesei $\mathrm{CBH} 1$, were completely conserved (Figure 5), the identity between the CBDs in GH6 and GH7 was only between 28 and 72\% (Figure S2). Noteworthy variation in CBD sequences included $\mathrm{Y}, \mathrm{F}, \mathrm{S}, \mathrm{T}, \mathrm{N}$ at position $26, \mathrm{~V}, \mathrm{~S}, \mathrm{~K}, \mathrm{R}, \mathrm{E}, \mathrm{Y}$ at position 30 , and W, Y, F, I, C at position 34. In particular, the CBD in V. mali GH6 has a Y at both 30 and 34 positions, while the residue at 26 is replaced by S (Figure 5). Aromatic residues at these positions may contribute to substrate binding and thus $\mathrm{CBH}$ activities [60]. A comparative biochemical study of GH6 CBHs from different fungi has shown variation in substrate interactions, adsorption capacity, and turnover number [61]. Variation in CBD sequence has further been shown to influence the adsorption and kinetics of GH6 CBH [62]. Taken together, the results of this and previous studies indicate the potential role of cellulase sequence and domain organization in host preferences of pathogenic fungi [39,62-64].

The carbohydrate-active enzyme (CAzyme) profile of pathogenic fungi further reflects variation in chemical and structural properties of host PCWs [65]. A clustering analysis indicates a unique profile of CAZymes for the pathogenic fungi (Figure 6), such as $V$. mali, an apple-tree-specific pathogen [20,38]. Compared to herbaceous pathogens, $V$. mali contains relatively low copy numbers of AA3 and AA9 genes, but relatively high numbers of $\mathrm{GH} 3$ and GH43. AA9 along with AA3 are known to be involved in cellulose degradation by cellulolytic fungi [66], while GH3 and GH43 are involved in hemicellulose degradation or modification $[67,68]$. High levels of GH3 and GH43 in the $V$. mali genome may reflect their potential role in its hydrolytic preference for the $A B$ substrate (Figure 1A). This is consistent with a decreased hydrolytic pereference of $V$. mali for the AB substrate after hemicellulase pretreatment (Figure 1B).

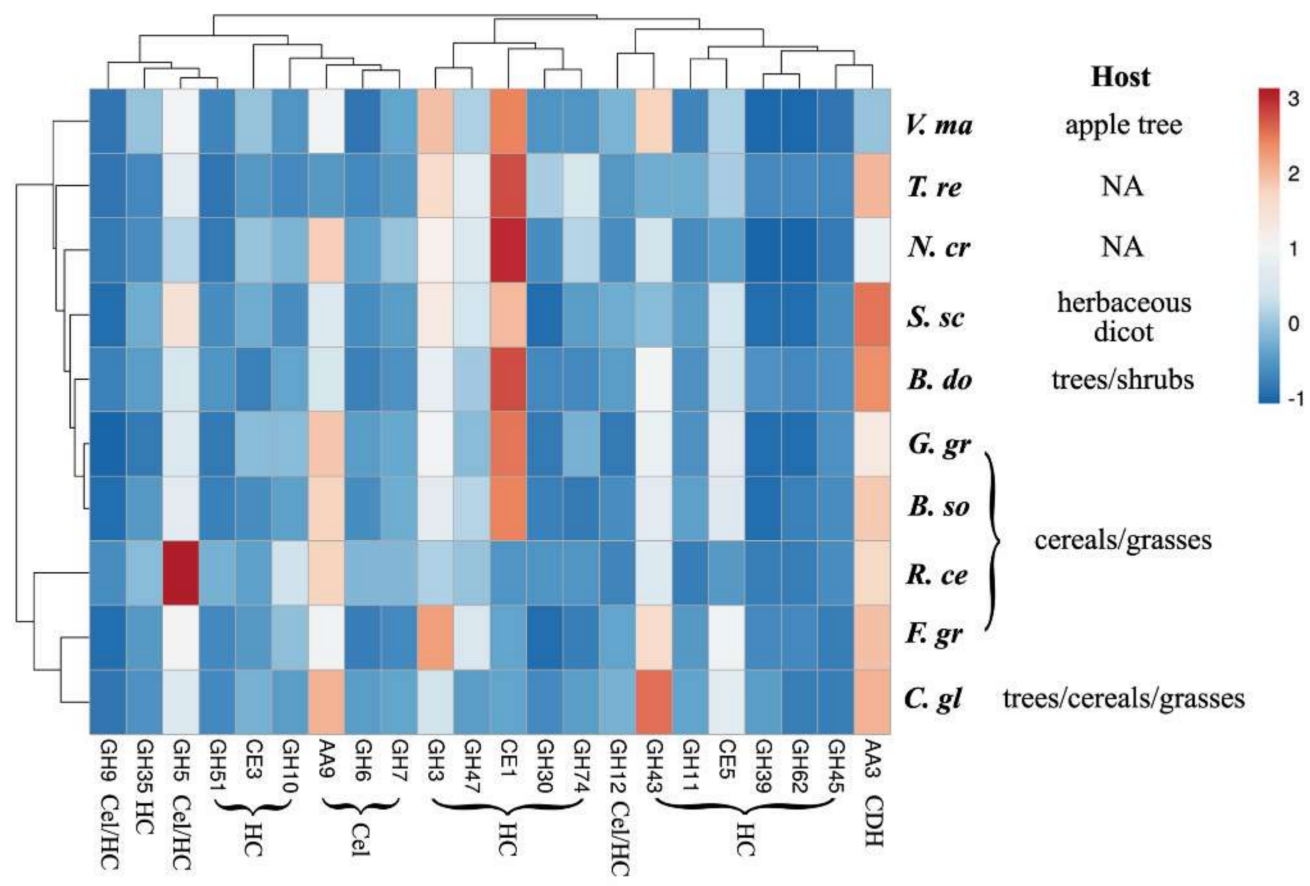

Figure 6. Hierarchical clustering of the pathogenic fungi tested, based on the abundance and composition of CAZyme classes. Heatmap shows the relative abundance of each CAZyme class. CAZymes categories include Glycoside Hydrolases (GHs), Carbohydrate Esterases (CEs), and Auxiliary Activities enzymes (AAs). Catalytic activities of the CAZymes include cellulase (Cel), hemicellulase (HC), and cellobiose dehydrogenase (CDH). The AA9 family consists of lytic polysaccharide monooxygenases (LPMOs) involved in cellulose degradation. A detailed description of the CAZymes is available on the CAZy database (http:/ / www.cazy.org, accessed on 16 November 2021). 


\section{Materials and Methods}

\subsection{Chemicals and Materials}

PCW biomass of wheat straw (WS), switchgrass straw (SW), rapeseed straw (RS), and apple tree branch $(\mathrm{AB})$ were obtained in Yangling, Shaanxi, China. The biomass samples were cut into $1 \mathrm{~cm}$ using a chopper, soaked in tap water for one day, dried for $72 \mathrm{~h}$ at $50{ }^{\circ} \mathrm{C}$ in a drying oven, and homogenized for $2 \mathrm{~min}$ in a blender, followed by sieving through a 35 -mesh screen. The sieved biomass was used for further experiments. The fungal strains used in this study were obtained from the College of Plant Protection and Shaanxi Key Laboratory of Molecular Biology for Agriculture, Northwest A\&F University, Yangling, Shaanxi, China. Chemicals were purchased from Sigma-Aldrich (St. Louis, MO, USA) or Solarbio (Beijing, China).

\subsection{Cultures and Growth Conditions}

Spores or mycelia of fungal isolates were stored in $20 \%$ glycerol at $-80{ }^{\circ} \mathrm{C}$. When inoculum was required, the isolates were sub-cultured on potato dextrose agar (PDA) and grown at $25{ }^{\circ} \mathrm{C}$, as previously described [39]. Then, $6 \mathrm{~mm}$ plugs of 7-day-old cultures were transferred to switchgrass-based agar media in $50 \mathrm{~mm}$ Petri dishes. The agar media were modified from the ATCC cellulose medium $907\left(0.5 \mathrm{~g}(\mathrm{NH} 4)_{2} \mathrm{SO}_{4}, 0.5 \mathrm{~g}\right.$ L-asparagine, $1 \mathrm{~g} \mathrm{KH}_{2} \mathrm{PO}_{4}, 0.5 \mathrm{~g} \mathrm{KCl}, 0.2 \mathrm{~g} \mathrm{MgSO}_{4}, 0.1 \mathrm{~g} \mathrm{CaCl}_{2}, 0.5 \mathrm{~g}$ yeast extract, $16 \mathrm{~g}$ agarose, $5 \mathrm{~g}$ dry switchgrass, $1 \mathrm{~L} \mathrm{H}_{2} \mathrm{O}$ ). Cultures were grown on the media for an additional 10 days before freezing at $-80^{\circ} \mathrm{C}$. Exoproteome samples were extracted from the cultures and frozen at $-80{ }^{\circ} \mathrm{C}$ until assayed as previously described [39].

\subsection{Microscale Enzymatic Saccharification}

The effectiveness of exoproteomes to hydrolyze raw and pretreated wheat straw, switchgrass, rapeseed straw, and apple tree branch biomass was assessed by enzymatic saccharification performed in 96-well flat-bottom microplates (Corning Life Sciences, Costar flat bottom 3370, Corning, NY, USA), as described previously [39,69]. Upon completion of saccharification, the samples were kept at $-20^{\circ} \mathrm{C}$ until further analysis. The total reducing sugars were quantified in a microplate format [69] using the DNS method, with glucose as the standard [70].

\subsection{Hemicellulase and Peracetic Acid Pretreatment}

Hemicellulase H2125 (Sigma) was from Aspergillus niger, containing a mixture of xylanase, mannanase, and other activities. Briefly, air-dried biomass powder was treated with hemicellulases at $350 \mathrm{U} / \mathrm{g}$ of biomass for $72 \mathrm{~h}$ at $50 \pm 2{ }^{\circ} \mathrm{C}$ or exoproteome of a pathogenic fungus at $200 \mathrm{mg} / \mathrm{g}$ of biomass for $12 \mathrm{~h}$ at $50 \pm 2{ }^{\circ} \mathrm{C}$ in a sodium acetate buffer containing $0.05 \mathrm{~g}$ of dry biomass powder per $\mathrm{ml}$ of buffer. After the pretreatment, enzymes were inactivated by incubating at $100^{\circ} \mathrm{C}$ for $10 \mathrm{~min}$. Pretreated biomass was washed with 10 volumes of distilled water three times to remove residual sugars. Pretreated samples were air-dried and stored at room temperature for further experiments.

Peracetic acid (PPA) pretreatment was applied for selective delignification at a final loading of $5.0 \mathrm{~g} / \mathrm{g}$ of biomass in a sodium acetate buffer containing $0.05 \mathrm{~g}$ of dry biomass powder per $\mathrm{ml}$ of buffer for $48 \mathrm{~h}$ at $25 \pm 2{ }^{\circ} \mathrm{C}$, as described previously [71]. Pretreated samples were neutralized by washing with distilled water. Pretreated samples were airdried and stored at room temperature for further experiments.

\subsection{Cell Wall Composition Analysis}

Biomass samples were incubated in a hot air oven maintained at $105^{\circ} \mathrm{C}$ until a constant weight was obtained. Extractive-based compositional analyses of the samples were performed according to the NREL LAPs [72,73]. Triplicate samples of approximately 0.3 $\mathrm{g}$ (dry basis) were weighed accurately into test tubes. $72 \%(w / w) \mathrm{H}_{2} \mathrm{SO}_{4}$ was added to each of the tubes to make a sample to acid ratio of $1 \mathrm{~g} / 10 \mathrm{~mL}$. The tubes were placed in a water bath set at $30^{\circ} \mathrm{C}$ for $1 \mathrm{~h}$ and were stirred in every 15 min with glass stirring 
rods. Each sample was diluted to $4 \%(w / w) \mathrm{H}_{2} \mathrm{SO}_{4}$ with distilled water, followed by a secondary hydrolysis performed in an autoclave at $121{ }^{\circ} \mathrm{C}$ for $1 \mathrm{~h}$ (liquid setting). The samples were rapidly cooled to room temperature on ice, and then filtered through $0.22 \mu \mathrm{m}$ MicroPES filters. The quantities of Klason lignin were determined gravimetrically [73]. Cellulose and hemicellulose contents were measured using an ICS 5000+ Ion Chromatography system equipped with a pulse-amperometric detector (Thermo Fisher Scientific, Waltham, MA, USA). A pre-flow of $200 \mathrm{mM} \mathrm{NaOH}$ for $15 \mathrm{~min}$, followed by $12 \mathrm{mM} \mathrm{NaOH}$ for $15 \mathrm{~min}$, was carried out to equilibrate a $4 \times 250 \mathrm{~mm}$ Dionex CarboPac PA10 column with a $4 \times 50 \mathrm{~mm}$ CarboPac PA10 BioLCTM guard column (Thermo Fisher Scientific) before injection of samples. A sample volume of $20 \mu \mathrm{L}$ was injected into the column and eluted at $30^{\circ} \mathrm{C}$ with $12 \mathrm{mM}$ sodium hydroxide at a flow rate of $1 \mathrm{~mL} / \mathrm{min}$. Cellulose, hemicellulose, and lignin contents were calculated as described previously [73,74].

\subsection{FESEM Imaging}

To prepare the cell wall fragments for FESEM imaging, AB, RS, SG, or WS was washed, dried, and homogenized as described above. The derived biomass was treated with PAA, followed by washing with water and drying in a drying oven. Samples were placed on a carbon tape attached to stubs and coated with approximately $1 \mathrm{~nm}$ of iridium. FESEM images were taken using a FEI Nova Nano SEM 450 FEG SEM operated at $10.0 \mathrm{kV}$ with a spot size of 3.0 as described in previous studies $[75,76]$.

\subsection{CAZyme Data Collection}

CAZyme data of F. graminearum, G. graminis, S. sclerotiorum, N. crassa and T. reesei were from the reference [65] and CAZy database (http:/ / www.cazy.org/, accessed on 16 November 2021). The data of $B$. dothidea were from the references $[22,77]$. The data of B. sorokinina, $C$. gloeosporioides, R. cerealis, and V. mali were from the references [38,78-80], respectively.

\subsection{GH6 and GH7 Gene Sequence Acquisition and Analysis}

Sequences of GH6 and GH7 CBH genes in T. reesei were retrieved from the UniProt portal (www.uniprot.org, accessed on 16 November 2021); these sequences were used to Blast in the MycoCosm (https: / / mycocosm.jgi.doe.gov/, accessed on 16 November 2021) or EnsemblFungi (http:/ / fungi.ensembl.org/, accessed on 16 November 2021) database to obtain GH6 and GH7 candidate genes coding sequences. The incomplete reading frame, short and redundant sequences were removed to obtain GH6 and GH7 genes and protein sequences. Multiple sequence alignments were conducted using MUSCLE [81] (https: / / www.ebi.ac.uk/Tools/msa/muscle/, accessed on 16 November 2021) and ESprint (http:/ / espript.ibcp.fr/ESPript/cgi-bin/ESPript.cgi, accessed on 16 November 2021). The phylogenetic analysis was performed based on amino acid sequences using the maximum likelihood method in the Mega X program [82]. A total of 1000 replicates were used to test the reliability of the branches. ITOL was used to generate interactive phylogenetic tree [83].

\subsection{Data Analysis and Statistics}

All experiments were conducted with at least three biological replicates. Student's $t$-test was used to analyze statistical significance between different variables. The heatmaps presented in Figures 1 and 6 were generated using ClustVis (http:/ / biit.cs.ut.ee/clustvis, accessed on 16 November 2021) [84].

\section{Conclusions}

Forest and agricultural residues are important renewable sources of biopolymers. In this study, the enzymatic digestibility of woody and herbaceous biomass by pathogenic fungi was compared before and after biomass pretreatment by hemicellulases and PAA. Preferred hydrolysis of apple tree branch (AB) (woody dicot), rapeseed straw (RS) (herbaceous dicot), or wheat straw (WS) (herbaceous monocot) were observed by Valsa mali, Rhizoctonia cerealis, or Sclerotinia sclerotiorum, respectively (Figure 1A). Hemicellulase pretreatment 
significantly changed hydrolytic preferences of the pathogenic fungi (Figure 1B). For instance, hemicellulase pretreatment switched the hydrolytic preference of $C$. gloeosporioides from $\mathrm{AB}$ to WS, while the pretreatment switched the preference of G. graminis from WS, SG, and RS to WS. Delignification by peracetic acid pretreatment enhanced the enzymatic digestibility of the biomass substrates tested (Figure 3D). It was noteworthy that the observed enhancement was generally more profound with non-host than host plant biomass. FESEM imaging showed different surface structures between the cell walls of apple tree and wheat or rapeseed straw, particularly in cellulose assembly and organization (Figure 4). The difference in woody and herbaceous cell wall structure was reflected by variation in PCWDEs of pathogenic fungi (Figures 5 and 6). Relatively high abundance of GH3 and GH43 hemicellulase genes was found in the V. mali genome compared to that of the herbaceous pathogens tested (Figure 5A). The woody pathogens, such as V. mali and Botryosphaeria dothidea, appeared to have a unique organization of cellulose-binding domain (CBD) in GH6 and GH7 cellobiohydrolases. Taken together, the results of this and previous studies support the hypotheses that woody and herbaceous plant cell walls form different interaction networks of cellulose, hemicelluloses, and lignin, and that pathogenic fungi have evolved host-specific arsenals of PCWDEs, reflected by their genomic composition, domain organization, and sequences.

Supplementary Materials: The following are available online. Figure S1. CBD organization in GH6 and GH7 cellulases. Figure S2. Identity in sequence alignment of CBDs from GH6 and GH7 cellulases.

Author Contributions: Conceptualization, S.C.; Data curation, Y.Y. and Y.W. (Yanping Wei); Formal analysis, Y.D. and Y.Y.; Funding acquisition, S.C.; Investigation, Y.D. and Y.Y.; Methodology, Y.D., Y.Y., Y.W. (Yanping Wei), L.W., Y.W. (Yifan Wang), P.D., Y.Z., J.L. (Johannes Liesche), L.H., H.F., C.Z., J.L. (Jisheng Li) and Y.W. (Yahong Wei); Project administration, J.L. (Johannes Liesche), Y.W. (Yahong Wei) and S.C.; Resources, L.W., L.H., H.F., C.Z. and Y.W. (Yahong Wei); Supervision, Y.W. (Yahong Wei) and S.C.; Validation, Y.D., N.K.M., Y.W. (Yanping Wei), L.W., Y.W. (Yifan Wang), Y.L., P.D., Y.Z. and J.L. (Jisheng Li); Visualization, N.K.M. and Y.L.; Writing-original draft, N.K.M., Y.L. and S.C.; Writing - review \& editing, S.C., Y.D. and Y.Y. should be considered joint first author. All authors have read and agreed to the published version of the manuscript.

Funding: This work was supported by the following grants: “The Twelfth Five-Year-Plan" in National Science and Technology for the Rural Development project (approval no. 2015BAD15B0503, to SC) from the Ministry of Science and Technology of PRC, the project (approval no. 31770207, to SC) from the National Natural Science Foundation of China, the Inter-Governmental International Science and Technology Innovation Cooperation project (approval no. 2018YFE0112400, to SC) from the Ministry of Science and Technology of PRC, and the Project of Shaanxi Association for Science and Technology(approval no. 2021-2-3, to YHW). These funders had no role in the study design, data collection and interpretation, or the decision to submit the work for publication.

Data Availability Statement: Data is contained within the article.

Acknowledgments: We are thankful to Lei Zhang, Bingcheng $X u$, and Yajun $X i$ for their support for strains and biomass substrates used in this study.

Conflicts of Interest: The authors declare no conflict of interest. The funders had no role in the design of the study; in the collection, analyses, or interpretation of data; in the writing of the manuscript, or in the decision to publish the results.

Sample Availability: Samples of the compounds are available from Sigma-Aldrich. 


\section{References}

1. Arthur, J.; Ragauskas, A.J.; Williams, C.K.; Davison, B.H.; Britovsek, G.; Cairney, J.; Eckert, C.A.; Frederick, W.J.; Hallett, J.P.; Leak, D.J.; et al. The path forward for biofuels and biomaterials. Science 2018, 311, 271-283. [CrossRef]

2. Davis, R.; Tao, L.; Tan, E.; Biddy, M.; Beckham, G.; Scarlata, C.; Jacobson, J.; Cafferty, K.; Ross, J.; Lukas, J. Process Design and Economics for the Conversion of Lignocellulosic Biomass to Hydrocarbons: Dilute-Acid and Enzymatic Deconstruction of Biomass to Sugars and Biological Conversion of Sugars to Hydrocarbons; National Renewable Energy Laboratory (NREL): Golden, CO, USA, 2013.

3. Humbird, D.; Davis, R.; Tao, L.; Kinchin, C.; Hsu, D.; Aden, A. Process Design and Economics for Biochemical Conversion of Lignocellulosic Biomass to Ethanol: Dilute-Acid Pretreatment and Enzymatic Hydrolysis of Corn Stover; National Renewable Energy Laboratory (NREL): Golden, CO, USA, 2011.

4. Klein-Marcuschamer, D.; Oleskowicz-Popiel, P.; Simmons, B.A.; Blanch, H.W. The challenge of enzyme cost in the production of lignocellulosic biofuels. Biotechnol. Bioeng. 2011, 109, 1083-1087. [CrossRef] [PubMed]

5. Ding, S.Y.; Liu, Y.S.; Zeng, Y.; Himmel, M.E.; Baker, J.O.; Bayer, E.A. How does plant cell wall nanoscale architecture correlate with enzymatic digestibility? Science 2012, 338, 1055-1060. [CrossRef]

6. Wilson, D.B. Microbial diversity of cellulose hydrolysis. Curr. Opin. Microbiol. 2011, 14, 259-263. [CrossRef] [PubMed]

7. Somerville, C.; Youngs, H.; Taylor, C.; Davis, S.C.; Long, S.P. Feedstocks for lignocellulosic biofuels. Science 2010, 329, 790-792. [CrossRef] [PubMed]

8. Fan, C.; Yu, H.; Qin, S.; Li, Y.; Alam, A.; Xu, C.; Fan, D.; Zhang, Q.; Wang, Y.; Zhu, W.; et al. Brassinosteroid overproduction improves lignocellulose quantity and quality to maximize bioethanol yield under green-like biomass process in transgenic poplar. Biotechnol. Biofuels 2020, 13, 1-17. [CrossRef]

9. Pauly, M.; Keegstra, K. Plant cell wall polymers as precursors for biofuels. Curr. Opin. Plant Biol. 2010, 13, 304-311. [CrossRef]

10. Busse-Wicher, M.; Li, A.; Silveira, R.L.; Pereira, C.S.; Tryfona, T.; Gomes, T.C.F.; Skaf, M.S.; Dupree, P. Evolution of xylan substitution patterns in gymnosperms and angiosperms: Implications for xylan interaction with cellulose. Plant Physiol. 2016, 171, 2418-2431. [CrossRef]

11. Scheller, H.V.; Ulvskov, P. Hemicelluloses. Annu. Rev. Plant Biol. 2010, 61, 263-289. [CrossRef] [PubMed]

12. Terrett, O.M.; Dupree, P. Covalent interactions between lignin and hemicelluloses in plant secondary cell walls. Curr. Opin. Biotechnol. 2019, 56, 97-104. [CrossRef] [PubMed]

13. Grantham, N.; Wurman-Rodrich, J.; Terrett, O.; Lyczakowski, J.; Stott, K.; Iuga, D.; Simmons, T.; Durand-Tardif, M.; Brown, S.; Dupree, R.; et al. An even pattern of xylan substitution is critical for interaction with cellulose in plant cell walls. Nat. Plants 2017, 3, 859-865. [CrossRef] [PubMed]

14. Gupta, M.; Rawal, T.B.; Dupree, P.; Smith, J.C.; Petridis, L. Spontaneous rearrangement of acetylated xylan on hydrophilic cellulose surfaces. Cellulose 2021, 28, 3327-3345. [CrossRef]

15. Tavares, E.Q.P.; De Souza, A.; Buckeridge, M.S. How endogenous plant cell-wall degradation mechanisms can help achieve higher efficiency in saccharification of biomass. J. Exp. Bot. 2015, 66, 4133-4143. [CrossRef]

16. Choi, J.-H.; Park, S.-Y.; Kim, J.-H.; Cho, S.-M.; Jang, S.-K.; Hong, C.; Choi, I.-G. Selective deconstruction of hemicellulose and lignin with producing derivatives by sequential pretreatment process for biorefining concept. Bioresour. Technol. 2019, 291,121913 [CrossRef] [PubMed]

17. Han, L.; Wang, X.; Spiertz, H.; Yang, L.; Zhou, Y.; Liu, J.; Xie, G. Spatio-temporal availability of field crop residues for biofuel production in Northwest and Southwest China. Bioenergy Res. 2014, 8, 402-414. [CrossRef]

18. Zhu, K.; Liu, Z.; Tan, X.; Lin, J.; Xu, D. Study on the ecological potential of Chinese straw resources available for bioenergy producing based on soil protection functions. Biomass Bioenergy 2018, 116, 26-38. [CrossRef]

19. Zhang, Y.; Tian, J.; Shen, Z.; Wang, W.; Ni, H.; Liu, S.; Cao, J. Emission characteristics of PM2.5 and trace gases from household wood burning in Guanzhong plain, Northwest China. Aerosol Sci. Eng. 2018, 2, 130-140. [CrossRef]

20. Wang, X.; Zang, R.; Yin, Z.; Kang, Z.; Huang, L. Delimiting cryptic pathogen species causing apple Valsa canker with multilocus data. Ecol. Evol. 2014, 4, 1369-1380. [CrossRef]

21. Dong, X.-L.; Cheng, Z.-Z.; Leng, W.-F.; Li, B.-H.; Xu, X.-M.; Lian, S.; Wang, C.-X. Progression of symptoms caused by Botryosphaeria dothidea on apple branches. Phytopathology 2021. [CrossRef]

22. Marsberg, A.; Kemler, M.; Jami, F.; Nagel, J.H.; Postma-Smidt, A.; Naidoo, S.; Wingfield, M.J.; Crous, P.W.; Spatafora, J.W.; Hesse, C.N.; et al. Botryosphaeria dothidea: A latent pathogen of global importance to woody plant health. Mol. Plant Pathol. 2017, 18, 477-488. [CrossRef]

23. Ajay Kumar, G. Colletotrichum gloeosporioides: Biology, pathogenicity and management in India. J. Plant Physiol. Pathol. 2014, 2, 2.

24. Boland, G.; Hall, R. Index of plant hosts of Sclerotinia sclerotiorum. Can. J. Plant Pathol. 1994, 16, 93-108. [CrossRef]

25. Fajolu, O.L.; Wadl, P.A.; Vu, A.L.; Gwinn, K.D.; Scheffler, B.E.; Trigiano, R.N.; Ownley, B.H. Development and characterization of simple sequence repeats for Bipolaris sorokiniana and cross transferability to related species. Mycologia 2013, 105, 1164-1173. [CrossRef]

26. Kumar, J.; Schäfer, P.; Hückelhoven, R.; Langen, G.; Baltruschat, H.; Stein, E.; Nagarajan, S.; Kogel, K.-H. Bipolaris sorokiniana, a cereal pathogen of global concern: Cytological and molecular approaches towards better control. Mol. Plant Pathol. 2002, 3, 185-195. [CrossRef] [PubMed]

27. Bryan, G.T.; Labourdette, E.; Melton, R.; Nicholson, P.; Daniels, M.J.; Osbourn, A.E. DNA polymorphism and host range in the take-all fungus, Gaeumannomyces graminis. Mycol. Res. 1999, 103, 319-327. [CrossRef] 
28. Harris, L.J.; Balcerzak, M.; Johnston, A.; Schneiderman, D.; Ouellet, T. Host-preferential Fusarium graminearum gene expression during infection of wheat, barley, and maize. Fungal Biol. 2016, 120, 111-123. [CrossRef]

29. Collins, S.B. Characterization of Fusarium Species and Alternaria Alternata, and Their Effects on Switchgrass Health and Chemical Components; University of Tennessee: Knoxville, TN, USA, 2016.

30. Freeman, J.; Ward, E. Gaeumannomyces graminis, the take-all fungus and its relatives. Mol. Plant Pathol. 2004, 5, 235-252. [CrossRef]

31. Etheridge, J.V.; Davey, L.; Christian, D.G. First report of Rhizoctonia cerealis causing sharp eyespot in Panicum virgatum in the UK. Plant Pathol. 2001, 50, 807. [CrossRef]

32. Hamada, M.S.; Yin, Y.; Chen, H.; Ma, Z. The escalating threat of Rhizoctonia cerealis, the causal agent of sharp eyespot in wheat. Pest Manag. Sci. 2011, 67, 1411-1419. [CrossRef] [PubMed]

33. Chen, S.; Ehrhardt, D.W.; Somerville, C.R. Mutations of cellulose synthase (CESA1) phosphorylation sites modulate anisotropic cell expansion and bidirectional mobility of cellulose synthase. Proc. Natl. Acad. Sci. USA 2010, 107, 17188-17193. [CrossRef] [PubMed]

34. Chen, S.; Jia, H.; Zhao, H.; Liu, D.; Liu, Y.; Liu, B.; Bauer, S.; Somerville, C.R. Anisotropic cell expansion is affected through the bidirectional mobility of cellulose synthase complexes and phosphorylation at two critical residues on CESA3. Plant Physiol. 2016, 171, 242-250. [CrossRef] [PubMed]

35. Liu, X.; Li, J.; Zhao, H.; Liu, B.; Pomorski, T.G.; Chen, S.; Liesche, J. Novel tool to quantify cell wall porosity relates wall structure to cell growth and drug uptake. J. Cell Biol. 2019, 218, 1408-1421. [CrossRef] [PubMed]

36. $\mathrm{Pu}, \mathrm{Y} . ; \mathrm{Hu}, \mathrm{F}$; Huang, F.; Davison, B.H.; Ragauskas, A.J. Assessing the molecular structure basis for biomass recalcitrance during dilute acid and hydrothermal pretreatments. Biotechnol. Biofuels 2013, 6, 15. [CrossRef]

37. Medve, J.; Lee, D.; Tjerneld, F. Ion-exchange chromatographic purification and quantitative analysis of Trichoderma reesei cellulases cellobiohydrolase I, II and endoglucanase II by fast protein liquid chromatography. J. Chromatogr. A 1998, 808, 153-165. [CrossRef]

38. Yin, Z.; Liu, H.; Li, Z.; Ke, X.; Dou, D.; Gao, X.; Song, N.; Dai, Q.; Wu, Y.; Xu, J.; et al. Genome sequence of Valsa canker pathogens uncovers a potential adaptation of colonization of woody bark. New Phytol. 2015, 208, 1202-1216. [CrossRef] [PubMed]

39. King, B.C.; Waxman, K.D.; Nenni, N.V.; Walker, L.P.; Bergstrom, G.C.; Gibson, D.M. Arsenal of plant cell wall degrading enzymes reflects host preference among plant pathogenic fungi. Biotechnol. Biofuels 2011, 4, 4. [CrossRef] [PubMed]

40. Yu, C.; Li, T.; Shi, X.; Saleem, M.; Li, B.; Liang, W.; Wang, C. Deletion of Endo- $\beta-1,4$-xylanase vmxyl1 impacts the virulence of Valsa mali in apple tree. Front. Plant Sci. 2018, 9, 663. [CrossRef]

41. Xu, M.; Gao, X.; Chen, J.; Yin, Z.; Feng, H.; Huang, L. The feruloyl esterase genes are required for full pathogenicity of the apple tree canker pathogen Valsa mali. Mol. Plant Pathol. 2017, 19, 1353-1363. [CrossRef]

42. Noda, J.; Brito, N.; González, C. The botrytis cinerea xylanase xyn11a contributes to virulence with its necrotizing activity, not with its catalytic activity. Bmc Plant Biol. 2010, 10, 38. [CrossRef]

43. Nguyen, Q.B.; Itoh, K.; Van Vu, B.; Tosa, Y.; Nakayashiki, H. Simultaneous silencing of endo- $\beta-1,4$ xylanase genes reveals their roles in the virulence of Magnaporthe oryzae. Mol. Microbiol. 2011, 81, 1008-1019. [CrossRef]

44. Thaker, A.; Mehta, K.; Patkar, R. Feruloyl esterase Fae1 is required specifically for host colonisation by the rice-blast fungus Magnaporthe oryzae. Res. Sq. 2021. [CrossRef] [PubMed]

45. Berglund, J.; Mikkelsen, D.; Flanagan, B.M.; Dhital, S.; Gaunitz, S.; Henriksson, G.; Lindström, M.E.; Yakubov, G.E.; Gidley, M.J.; Vilaplana, F. Wood hemicelluloses exert distinct biomechanical contributions to cellulose fibrillar networks. Nat. Commun. 2020, 11, 4692. [CrossRef] [PubMed]

46. Alemdar, A.; Sain, M. Isolation and characterization of nanofibers from agricultural residues-Wheat straw and soy hulls. Bioresour. Technol. 2008, 99, 1664-1671. [CrossRef] [PubMed]

47. Xu, B.; Escamilla-Treviño, L.L.; Sathitsuksanoh, N.; Shen, Z.; Shen, H.; Zhang, Y.-H.P.; Dixon, R.A.; Zhao, B. Silencing of 4-coumarate:coenzyme A ligase in switchgrass leads to reduced lignin content and improved fermentable sugar yields for biofuel production. New Phytol. 2011, 192, 611-625. [CrossRef] [PubMed]

48. Lu, X.; Zhang, Y.; Angelidaki, I. Optimization of $\mathrm{H}_{2} \mathrm{SO}_{4}$-catalyzed hydrothermal pretreatment of rapeseed straw for bioconversion to ethanol: Focusing on pretreatment at high solids content. Bioresour. Technol. 2009, 100, 3048-3053. [CrossRef]

49. Lyu, S.; Du, G.; Yang, Y. Apple branch decomposition and nutrient turnover in the orchard soil. Bioresources 2017, 12, 3108-3121. [CrossRef]

50. Jiang, B.; Yu, J.; Luo, X.; Zhu, Y.; Jin, Y. A strategy to improve enzymatic saccharification of wheat straw by adding water-soluble lignin prepared from alkali pretreatment spent liquor. Process. Biochem. 2018, 71, 147-151. [CrossRef]

51. Qiu, J.; Tian, D.; Shen, F.; Hu, J.; Zeng, Y.; Yang, G.; Zhang, Y.; Deng, S.; Zhang, J. Bioethanol production from wheat straw by phosphoric acid plus hydrogen peroxide (PHP) pretreatment via simultaneous saccharification and fermentation (SSF) at high solid loadings. Bioresour. Technol. 2018, 268, 355-362. [CrossRef] [PubMed]

52. Liu, J.; Wang, M.L.; Tonnis, B.; Habteselassie, M.; Liao, X.; Huang, Q. Fungal pretreatment of switchgrass for improved saccharification and simultaneous enzyme production. Bioresour. Technol. 2013, 135, 39-45. [CrossRef]

53. Zhang, D.; Yang, Q.; Zhu, J.; Pan, X. Sulfite (SPORL) pretreatment of switchgrass for enzymatic saccharification. Bioresour. Technol. 2012, 129, 127-134. [CrossRef] [PubMed]

54. Karagöz, P.; Rocha, I.V.; Özkan, M.; Angelidaki, I. Alkaline peroxide pretreatment of rapeseed straw for enhancing bioethanol production by same vessel saccharification and co-fermentation. Bioresour. Technol. 2012, 104, 349-357. [CrossRef] [PubMed] 
55. Zeng, Y.; Zhao, S.; Yang, S.; Ding, S.-Y. Lignin plays a negative role in the biochemical process for producing lignocellulosic biofuels. Curr. Opin. Biotechnol. 2014, 27, 38-45. [CrossRef] [PubMed]

56. Penttilä, P.A.; Altgen, M.; Awais, M.; Österberg, M.; Rautkari, L.; Schweins, R. Bundling of cellulose microfibrils in native and polyethylene glycol-containing wood cell walls revealed by small-angle neutron scattering. Sci. Rep. 2020, 10, 1-9. [CrossRef] [PubMed]

57. Wilson, T.H.; Kumar, M.; Turner, S.R. The molecular basis of plant cellulose synthase complex organisation and assembly. Biochem. Soc. Trans. 2021, 49, 379-391. [CrossRef] [PubMed]

58. Carroll, A.; Specht, C.D. Understanding plant cellulose synthases through a comprehensive investigation of the cellulose synthase family sequences. Front. Plant Sci. 2011, 2, 5. [CrossRef] [PubMed]

59. Payne, C.M.; Knott, B.C.; Mayes, H.B.; Hansson, H.; Himmel, M.E.; Sandgren, M.; Stahlberg, J.; Beckham, G.T. Fungal cellulases. Chem. Rev. 2015, 115, 1308-1448. [CrossRef] [PubMed]

60. Yan, S.; Wu, G. Implications of carbohydrate binding modules of cellulases summarized from visualization. In Proceedings of the 2020 22nd International Conference on Transparent Optical Networks (ICTON), Bari, Italy, 19-23 July 2020; pp. 1-7. [CrossRef]

61. Christensen, S.J.; Krogh, K.B.R.M.; Spodsberg, N.; Borch, K.; Westh, P. A biochemical comparison of fungal GH6 cellobiohydrolases. Biochem. J. 2019, 476, 2157-2172. [CrossRef]

62. Christensen, S.J.; Badino, S.F.; Cavaleiro, A.M.; Borch, K.; Westh, P. Functional analysis of chimeric TrCel6A enzymes with different carbohydrate binding modules. Protein Eng. Des. Sel. 2019, 32, 401-409. [CrossRef] [PubMed]

63. Kubicek, C.P.; Starr, T.L.; Glass, N.L. Plant cell wall-degrading enzymes and their secretion in plant-pathogenic fungi. In Annual Review of Phytopathology; Van Alfen, N.K., Ed.; Annual Reviews: Palo Alto, CA, USA, 2014; Volume 52, pp. 427-451. [CrossRef]

64. Sidar, A.; Albuquerque, E.D.; Voshol, G.P.; Ram, A.F.J.; Vijgenboom, E.; Punt, P.J. Carbohydrate binding modules: Diversity of domain architecture in amylases and cellulases from filamentous microorganisms. Front. Bioeng. Biotechnol. 2020, 8, 871. [CrossRef] [PubMed]

65. Zhao, Z.; Liu, H.; Wang, C.; Xu, J.-R. Erratum to: Comparative analysis of fungal genomes reveals different plant cell wall degrading capacity in fungi. BMC Genom. 2014, 15, 6. [CrossRef]

66. Zarattini, M.; Corso, M.; Kadowaki, M.A.; Monclaro, A.; Magri, S.; Milanese, I.; Jolivet, S.; de Godoy, M.O.; Hermans, C.; Fagard, M.; et al. LPMO-oxidized cellulose oligosaccharides evoke immunity in Arabidopsis conferring resistance towards necrotrophic fungus B. cinerea. Commun. Biol. 2021, 4, 1-13. [CrossRef] [PubMed]

67. Mewis, K.; Lenfant, N.; Lombard, V.; Henrissat, B. Dividing the large glycoside hydrolase family 43 into subfamilies: A motivation for detailed enzyme characterization. Appl. Env. Microbiol. 2016, 82, 1686-1692. [CrossRef] [PubMed]

68. Méndez-Líter, J.A.; de Eugenio, L.I.; Nieto-Domínguez, M.; Prieto, A.; Martínez, M.J. Hemicellulases from Penicillium and Talaromyces for lignocellulosic biomass valorization: A review. Bioresour. Technol. 2020, 324, 124623. [CrossRef]

69. King, B.C.; Donnelly, M.K.; Bergstrom, G.C.; Walker, L.P.; Gibson, D.M. An optimized microplate assay system for quantitative evaluation of plant cell wall-degrading enzyme activity of fungal culture extracts. Biotechnol. Bioeng. 2009, 102, 1033-1044. [CrossRef]

70. Miller, G.L. Use of dinitrosalicylic acid reagent for determination of reducing sugar. Anal. Chem. 1959, 31, 426-428. [CrossRef]

71. Chang, V.S.; Holtzapple, M.T. Fundamental factors affecting biomass enzymatic reactivity. Appl. Biochem. Biotechnol. Part A Enzym. Eng. Biotechnol. 2000, 38, 5-37. [CrossRef]

72. Hames, B.; Ruiz, R.; Scarlata, C.; Sluiter, A.; Sluiter, J.; Templeton, D. Preparation of samples for compositional analysis. Lab. Anal. Proced. 2008, 1617, 65-71.

73. Sluiter, A.; Hames, B.; Ruiz, R.; Scarlata, C.; Sluiter, J.; Templeton, D.; Crocker, D. Determination of Structural Carbohydrates and Lignin in Biomass, Laboratory Analytical Procedure; National Renewable Energy Laboratory: Golden, CO, USA, 2011. Available online: https://www.nrel.gov/docs/gen/fy13/42618.pdf (accessed on 8 November 2021).

74. Zhang, M.; Zheng, R.; Chen, J.; Huang, H. Investigation on the determination of lignocellulosics components by NREL method. Chin. J. Anal. Lab. 2010, 29, 15-18.

75. Carpita, N.C.; Defernez, M.; Findlay, K.; Wells, B.; Shoue, D.A.; Catchpole, G.; Wilson, R.H.; McCann, M.C. Cell wall architecture of the elongating maize coleoptile. Plant Physiol. 2001, 127, 551-565. [CrossRef]

76. Zheng, Y.; Cosgrove, D.J.; Ning, G. High-resolution field emission scanning electron microscopy (FESEM) imaging of cellulose microfibril organization in plant primary cell walls. Microsc. Microanal. 2017, 23, 1048-1054. [CrossRef] [PubMed]

77. Wang, B.; Liang, X.; Gleason, M.L.; Zhang, R.; Sun, G. Comparative genomics of Botryosphaeria dothidea and B kuwatsukai, causal agents of apple ring rot, reveals both species expansion of pathogenicity-related genes and variations in virulence gene content during speciation. IMA Fungus 2018, 9, 243-257. [CrossRef] [PubMed]

78. Zaccaron, A.Z.; Bluhm, B.H. The genome sequence of Bipolaris cookei reveals mechanisms of pathogenesis underlying target leaf spot of sorghum. Sci. Rep. 2017, 7, 1-15. [CrossRef]

79. Baroncelli, R.; Amby, D.B.; Zapparata, A.; Sarrocco, S.; Vannacci, G.; Le Floch, G.; Harrison, R.J.; Holub, E.; Sukno, S.A.; Sreenivasaprasad, S.; et al. Gene family expansions and contractions are associated with host range in plant pathogens of the genus Colletotrichum. BMC Genom. 2016, 17, 1-17. [CrossRef] [PubMed]

80. Lin, L.; Feilong, G.; Zhichao, Z.; Lijun, P.; Yu, H.; Xiuliang, Z.; Jinfeng, Y.; Wenwu, Y.; Zengyan, Z. High-quality genome assembly-based and functional analyses reveal the pathogenesis mechanisms and evolutionary landscape of wheat sharp eyespot Rhizoctonia cerealis. Res. Sq. 2021. [CrossRef] 
81. Edgar, R.C. MUSCLE: Multiple sequence alignment with high accuracy and high throughput. Nucleic Acids Res. 2004, 32, $1792-1797$. [CrossRef] [PubMed]

82. Kumar, S.; Stecher, G.; Li, M.; Knyaz, C.; Tamura, K. MEGA X: Molecular evolutionary genetics analysis across computing platforms. Mol. Biol. Evol. 2018, 35, 1547-1549. [CrossRef] [PubMed]

83. Letunic, I.; Bork, P. Interactive tree of life (iTOL) v5: An online tool for phylogenetic tree display and annotation. Nucleic Acids Res. 2021, 49, W293-W296. [CrossRef] [PubMed]

84. Metsalu, T.; Vilo, J. ClustVis: A web tool for visualizing clustering of multivariate data using principal component analysis and heatmap. Nucleic Acids Res. 2015, 43, W566-W570. [CrossRef] [PubMed] 